\title{
Studi Tentang Perkembangan Kesabaran Anak 4-5 Tahun Melalui Budaya Antre di TK Bina Kasih Terpadu
}

\author{
Syukbertien Kariani Lombu \\ Sekolah Tinggi Agama Kristen Terpadu Salatiga \\ Email: tienlombu@gmail.com \\ Eny Suprihatin \\ Sekolah Tinggi Agama Kristen Terpadu Salatiga \\ Email: prihatineny67@yahoo.co.id
}

\begin{abstract}
The research entitled The Study of the Development of Patience of Children 4-5 Years through Queuing Culture at Bina Kasih Terpadu Kindergarten, Rumah Sumbul Village, Sibolangit District, Deli Serdang Regency, North Sumatra Province, aims to explore the results of queuing cultural habituation for Kindergarten A students in terms of development. patience. This type of research is field research (field research) using qualitative descriptive methods, which try to reveal the facts as they are. Qualitative research is an indepth study. Field research steps were carried out using descriptive data in the form of written and spoken words, observations of behavior and phenomena. Qualitative research emphasizes the meaning, reasoning, and definition of certain situations in certain contexts. Researching everyday life. The study was conducted on 9 children. From observations, it appears that children push each other and overtake when getting off the school bus, push friends when shaking hands with the teacher, place shoes carelessly on the shelf when entering class, run while washing their hands and run around on the bus when they come home from school. Therefore, it is interesting to study the development of patience for children aged 4-5 years through the habit of queuing. Data were collected through observation, interviews and documentation. The habit of queuing starts at 08:00 WIB when the children get off the bus, at 08:30 WIB when entering class, at 10:30 WIB when washing their hands and at 11:00 WIB when the children take the bus back home. The results showed that through habituation queuing was able to develop patience in Bina Kasih Terpadu Kindergarten children group A. The conclusion was that children's patience could be developed through habituation. In this case it is the cultural habituation of queuing.
\end{abstract}

Keywords: Patience Development, Queuing Culture, Children Aged 4-5 Years

\section{Abstrak}

Penelitian dengan judul Studi Tentang Perkembangan Kesabaran Anak 4-5 Tahun Melalui Budaya Antre di TK Bina Kasih Terpadu, Desa Rumah Sumbul, Kecamatan Sibolangit, Kabupaten Deli Serdang, Provinsi Sumatera Utara, bertujuan untuk mendalami hasil pembiasaan budaya antre bagi siswa TK A dalam hal perkembangan kesabaran. Jenis 
penelitian ini adalah Penelitian lapangan (field research) menggunakan metode deskriptif kualitatif, yang berusaha mengungkapkan fakta apa adanya. Penelitian kualitatif merupakan penyelidikan mendalam (indepth study). Dilakukan langkah-langkah penelitian lapangan menggunakan data deskriptif berupa kata-kata tertulis maupun lisan, pengamatan perilaku serta fenomena-fenomena. Penelitian kualitatif memberikan penekanan pada makna, penalaran, definisi situasi tertentu dalam konteks tertentu. Meneliti kehidupan sehari-hari. Penelitian dilakukan pada 9 anak. Dari pengamatan tampak anak saling dorong dan mendahului saat turun dari bus sekolah, mendorong teman saat bersalaman dengan guru, meletakkan sepatu dengan sembarangan di rak ketika masuk kelas, berlari saat mencuci tangan dan berlarian naik bus saat pulang sekolah. Oleh sebab itu menarik untuk diteliti perkembangan kesabaran anak usia 4-5 tahun melalui pembiasaan antre. Data dikumpulkan melalui pengamatan, wawancara dan dokumentasi. Pembiasaan antre dilakukan mulai jam 08:00 WIB saat anak-anak turun dari bus, jam 08:30 WIB saat masuk dalam kelas, jam 10:30 WIB saat mencuci tangan dan jam 11:00 WIB saat anak-anak naik bus pulang ke rumah. Hasil penelitian menunjukkan bahwa melalui pembiasaan antre mampu mengembangkan kesabaran pada anak TK Bina Kasih Terpadu kelompok A. Kesimpulannya adalah bahwa kesabaran anak dapat dikembangkan dengan jalan pembiasaan. Dalam hal ini adalah pembiasaan budaya antre.

Kata Kunci: Perkembangan Kesabaran, Budaya Antre, Anak Usia 4-5 Tahun

\section{Pendahuluan}

$\begin{array}{cccc}\text { Pada } & \text { umumnya } & \text { kata } & \text { sabar } \\ \text { didefinisikan } & \text { sebagai } & \text { sikap } & \text { tabah }\end{array}$ menghadapi sesuatu yang sulit, berat, dan pahit dengan diterima penuh tanggung jawab (Paulinus Yan Olla MSF: 2008).

Kesabaran anak harus dikembangkan dengan cara dibiasakan sejak dini, agar terbiasa bersabar dalam melakukan suatu kegiatan. Orang tua dan guru berperan besar serta sangat menentukan perkembangan hal tersebut. Hal serupa pun dikatakan oleh Frets Keriapy bahwa kebiasan yang baik harus diterapkan sejak di sekolah (Keriapy, 2020).

Perilaku yang diharapkan dari perkembangan sosial emosional anak salah satunya adalah kesabaran. Orang tua dan guru harus memaksimalkan pendidikan sosial emosional anak sejak usia dini. Pendidikan social emosional akan sangat efektif apabila mengacu pada norma yang berlaku disertai penguatan dari lingkungan sosialnya. Sebagai contoh: saat anak-anak berjalan di jalan raya harus tertib dan berjalan di sebelah kiri, tanpa harus saling mendahului.

Membina anak usia 4-5 tahun untuk memiliki perilaku sabar tidak mungkin hanya dengan menggunakan penjelasan atau diberi pengertian saja. Perlu bimbingan, keteladanan orang tua dan guru, serta praktek langsung agar anak mengerti dan mengaplikasikannya. Pendidik harus bersabar dalam proses tersebut karena setiap anak memiliki 
kebiasaan dan perilaku serta pemahaman yang berbeda.

Budaya antre yang ditanamkan diharap akan membuat anak meninggalkan kebiasaan buruk yang dilakukan sebelumnya. Seperti: mendahului dan mendorong teman di depannya saat masuk kelas, berebut bersalaman dengan guru, tidak sabar mencuci tangan dan meletakkan barang-barang di tempat semula.

Cara paling tepat memberikan pendidikan bagi anak usia dini dengan bermain, meniru, mengamati, dan mengeksplorasi pengalaman, memberi kesempatan kepada anak untuk memahami lingkungannya (Romini \& Harefa, 2020). Budaya antre yang diajarkan dan dibiasakan akan mendorong perkembangan kesabaran anak sehingga menjadi karakter baik dalam dirinya.

Siswa Taman Kanak-Kanak Bina Kasih Terpadu usia 4-5 tahun berjumlah sembilan. Dari pengamatan, siswa baru masuk di pendidikan ini, harus diajar dan dibiasakan dalam hal antre dan bersabar. Tampak saling mendahului dan mendorong teman saat turun dari bus sekolah. Mendorong teman saat bersalaman dengan guru. Meletakkan sepatu sembarangan di rak sepatu ketika akan masuk dalam kelas. Berlarian ketika hendak mencuci tangan di luar kelas dan berlarian ketika naik bus saat pulang sekolah.

Dalam hal ini, tenaga pendidik harus menyadari tanggung jawabnya. Seorang guru adalah pembimbing, pendidik, pengarah, pendamping, fasilitator, serta pemberi dukungan dalam melatih kesabaran anak usia dini. Hal yang dapat dilakukan oleh guru dalam melatih kesabaran adalah bekerja sama dengan anak untuk melaksanakan budaya antre sebagai bagian dalam mengembangkan kesabaran anak.

Berdasarkan pendahuluan di atas maka diadakan suatu penelitian kualitatif dengan judul : "Studi Perkembangan Kesabaran Anak Usia 4-5 Tahun Melalui Budaya Antre di TK Kristen Benih Kasih Terpadu."

Permasalahan penelitian dirumuskan sebagai berikut: Pertama, bagaimana perilaku sabar murid TK Kristen Benih Kasih Terpadu? Kedua, bagaimana pembiasaan budaya antre di TK Kristen Benih Kasih Terpadu? Ketiga, bagaimana perkembangan kesabaran anak melalui pembiasaan budaya antre di TK Kristen Benih Kasih Terpadu?

Tujuan penelitian adalah: Pertama, mendeskripsikan perilaku sabar murid TK Kristen Benih Kasih Terpadu? Kedua, mendeskripsikan pembiasaan budaya antre di TK Kristen Benih Kasih Terpadu? Ketiga, mendeskripsikan perkembangan 
kesabaran anak melalui pembiasaan budaya antre di TK Kristen Benih Kasih Terpadu?

\section{Tinjauan Pustaka}

Berikut tinjauan beberapa teori yang berkaitan dengan dengan objek penelitian yaitu: perkembangan kesabaran, budaya antre, dan anak usia 4-5 tahun.

Perkembangan Kesabaran. Anak usia empat tahun mulai mengerti tentang norma-norma. Kata-kata "baik", "buruk", "tidak boleh", dan sebagainya menjadi tanda-tanda untuk mengatur perilaku mereka dalam bersosialisasi (Monks et al., 2002). Perilaku sosial adalah segala kegiatan yang melibatkan atau terhubung dengan orang lain. Diperlukan perilaku yang dapat diterima semua. Anak akan melakukan perilaku yang dapat diterima orang lain untuk mengembangkan sikap sosial tertentu, dalam hal ini sikap sabar, agar dapat diterima dalam lingkungannya (Akilasari et al., 2015).

Rasa penasarannya mengalami perkembangan pesat sehingga akan berusaha mencari tahu sampai mengerti. Orang dewasa dalam hal ini orang tua dan pendidik harus benar-benar memerhatikan perkembangan kesabaran anak.

Perilaku sabar dapat dikembangkan melalui proses pembiasaan dan keteladanan (Cahyaningrum et al., 2017). Pendidik, baik itu orang tua maupun guru memberi contoh dengan memanfaatkan kebiasaan anak.

Listyan dari mengungkapkan keuntungan bagi anak ketika bersabar. Pertama, pandai mengendalikan emosi. Anak yang sabar pasti pandai mengendalikan emosinya, berhati-hati dan tidak terburu-buru ketika mengerjakan sesuatu sehingga hasilnya bagus. Anak juga tidak cepat marah ketika dipermalukan teman. Kedua, disayang teman dan disegani banyak orang. Karena memiliki sikap positif maka anak yang sabar disukai teman-temannya. Temanteman menjadi segan karena tahan diejek dan tidak emosional. Ketiga, mudah mengatasi kesulitan. Anak yang sabar mampu berpikir jernih sehingga dapat memecahkan persoalan dengan perhitungan matang. Keempat, cita-cita dapat dicapai dengan baik. Kesuksesan diraih dengan kesabaran dan ketelatenan dalam belajar dan berusaha. Dengan pikiran jernih untuk mengatasi halangan, sabar menghadapi ejekan dan kritikan (Listyandari, 2013).

Jadi disimpulkan bahwa kesabaran adalah bagian dari kecerdasan sosio emosional. Suatu perilaku yang mengandung faktor tidak lekas marah dan putus asa. Tahan menghadapi cobaan, tabah. Dapat diartikan juga sebagai bentuk sikap tenang, tidak terburu dan tergesagesa dalam melakukan segala sesuatu. 
Budaya antre. Diawali dengan pengertian budaya. Etnografi dikenal dengan uraian rinci (thick description). Budaya dari sudut pandang etnografi merupakan bagian penafsiran terhadap kehidupan pengertian akal sehat yang rumit dan sukar dipisahkan dari yang lainnya. Budaya merupakan hasil pengetahuan yang diperoleh manusia digunakan untuk menafsirkan pengalaman yang kemudian membentuk perilaku (Lexy, 2002).

\section{Zainal mengutip pernyataan E.B} Tylor, menyatakan: budaya merupakan suatu keseluruhan kompleks meliputi: pengetahuan, kepercayaan, kesenian, moral, keilmuan, hukum, adat-istiadat, dan kemampuan yang lain, serta kebiasaan yang didapat manusia sebagai anggota masyarakat (Zainal, 2012). Zainal juga mengutip pernyataan Robert Linton sebagai berikut: budaya dipandang sebagai wujud tingkah laku yang dipelajari dan hasil tingkah laku tersebut unsur pembentuknya didukung dan diteruskan oleh anggota masyarakat lainnya (Zainal, 2012).

\section{Koentjaraningrat mengatakan} budaya atau kebudayaan adalah hasil pemikiran, karya dan kehendak manusia yang didapat sesudah melalui proses belajar (Koentjaraningrat, 1981).

Disimpulkan, budaya adalah konfigurasi perilaku manusia yang didapat melewati proses pembelajaran jangka panjang kemudian didukung dan diteruskan anggota masyarakat lainnya. Dalam tulisan ini adalah budaya antre yang diajarkan oleh guru TK Bina Kasih melalui proses belajar selama anak-anak bersekolah.

Antre adalah perilaku sosial sekumpulan orang yang memiliki kesamaan minat, kebutuhan, keinginan, dan berkepentingan untuk memenuhinya, tetapi karena adanya tuntutan waktu dan keterbatasan sumber daya mengharuskan setiap orang mengikuti aturan pelayanan secara bergiliran (Hidayah, 2008).

Budaya antre merupakan hal baik yang harus ditanamkan sejak dini. Banyak kasus dalam berbagai situasi terdapat oknum yang tidak mau antre. Semua ingin menjadi yang terdepan dan saling mendahului. Kebiasaan sabar mengantre dapat memberi rasa aman dan nyaman bagi pihak yang berada dalam situasi tersebut (Ismiyati et al., 2016).

Mengantre merupakan hal yang sederhana, tetapi sangat tidak mudah untuk diterapkan dalam kehidupan sehari-hari. Dibutuhkan stimulus yang tepat pada anak usia dini untuk menyadari pentingnya budaya antre. Tentu saja metode disesuaikan dengan pertumbuhan dan perkembangan anak.

Guru dan orang tua berperan dalam membudayakan kebiasaan antre bagi anak 
di sekolah juga rumah. Kebiasaan antre harus terus-menerus dilakukan dan diteladankan supaya menjadi sebuah budaya, yaitu sesuatu yang melekat dalam hidup anak-anak. Hal yang sama nanti akan diteruskan pada anak-anak keturunan selanjutnya.

Anak 4-5 tahun. Studi perkembangan anak usia 4-5 tahun. Masganti mengutip pendapat Santrock memberikan definisi perkembangan (development) adalah "development is the pattern of change that begins at conception and continues though the life span." Artinya perkembangan adalah sebuah pola perubahan mulai sejak konsepsi terus berlangsung sepanjang kehidupan.(Sit, 2017)

Cara memahami anak banyak diambil dari konsep ilmu perkembangan anak. Sebuah cabang ilmu psikologi yang khusus memerhatikan tahapan tumbuh kembang kehidupan seorang anak sejak kelahirannya. Konsep tumbuh kembang anak dipahami sebagai tahapan tumbuh kembang kemampuan dan kompetensi anak (Budiardjo, 2011).

Monks mengutip pernyataan Werner mengatakan: perkembangan menunjuk suatu proses ke arah kesempurnaan dan tidak dapat diulang kembali. Perkembangan bersifat tetap dan tidak dapat diulang (Monks et al., 2002).

Pada usia 4 atau 5, anak mulai bermain dalam kelompok. Saling berbicara saat bermain, dan memilih siapa akan diajak bermain bersama. Hal paling umum dilakukan kelompok ini adalah saling mengamati, melakukan percakapan, dan memberikan saran lisan (Hurlock, 1978).

Dalam kondisi inilah anak-anak belajar bersabar untuk menunggu giliran dalam bermain dalam kelompoknya. Serta belajar mengembangkan sosio emosionalnya.

Perkembangan dipengaruhi oleh perubahan budaya. Individu dibentuk untuk menyesuaikan diri dengan standar budaya dan segala hal yang ideal. Perubahan-perubahan dalam standar tersebut akan memengaruhi pola perkembangan (Hurlock, 1978).

Berdasarkan pendapat di atas, disimpulkan bahwa perilaku sosial anak umur 4-5 tahun sangat dipengaruhi oleh perubahan budaya di lingkungannya. Anak belajar mengembangkan sosio emosionalnya.

\section{Metode Penelitian}

Jenis penelitian ini adalah Penelitian lapangan (field research). Menggunakan metode deskriptif kualitatif yang berusaha mengungkapkan data apa adanya. 
Moleong mengutip pernyataan

Denzin dan Lincoln mengatakan bahwa: penelitian kualitatif merupakan penelitian alamiah dengan maksud menafsirkan fenomena yang terjadi dan dilakukan dengan melibatkan berbagai metode yang ada (Lexy, 2002).

Cara Ilmiah kualitatif digunakan dalam penelitian agar dapat memeroleh makna di balik data. Sehingga ditemukan kebenaran, baik kebenaran, empiris logis untuk mengetahui tentang pengalaman atau pengetahuan manusia. Empiris berarti pengalaman yang pernah dilakukan oleh manusia dan dapat dilihat sehingga dapat dipahami oleh orang lain secara sistematik (Lexy, 2002).

Subjek penelitian adalah murid kelompok A TK Kristen Bina Kasih Terpadu berjumlah 9 siswa terdiri atas tujuh laki-laki dan dua perempuan.

Variabel penelitian. Penelitian "Studi Tentang Perkembangan Kesabaran Anak melalui Budaya Antre Pada Anak 4-5 Tahun di TK Kristen Benih Kasih Terpadu" memiliki dua variabel yaitu Perkembangan Kesabaran Anakdanbudaya antre. Budaya antre ditetapkan sebagai variabel satu atau variabel $\mathrm{X}$ sedangkan perkembangan kesabaran anak adalah variabel kedua atau variabel Y. Hubungan kedua variabel tersebut dapat digambarkan:
Variabel Penelitian

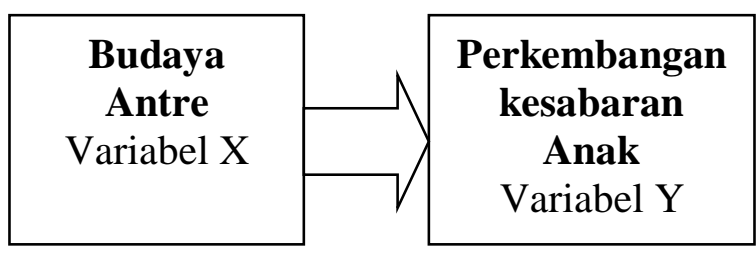

Gambar di atas dapat dijelaskan sebagai berikut: Budaya Antre, penetapan variabel $\mathrm{X}$ untuk mengetahui sejauh mana pengaruh pembiasaan budaya antre terhadap perkembangan kesabaran anak usia 4-5 tahun di TK Kristen Bina Kasih Terpadu. Selain itu, untuk mengetahui pembiasaan budaya antre dalam proses pembelajaran sebagai upaya mengembangkan kesabaran anak. Perkembangan kesabaran anak, perkembangan kesabaran anak sebagai variabel $\mathrm{Y}$ adalah untuk mengetahui perkembangan kesabaran anak setelah dilakukan penelitian apakah terjadi perkembangan sesuai harapan.

Metode pengumpulan data yang benar akan menghasilkan data dengan kredibilitas tinggi. Karenanya tahap pengumpulan data harus benar dan dilakukan dengan cermat sesuai prosedur serta ciri-ciri penelitian kualitatif (Sujarwati, 2014)

Dalam penelitian kualitatif, peneliti merupakan instrumen penelitian sekaligus pengumpul data, oleh karena itu kehadiran peneliti di lapangan mutlak diperlukan. Peneliti kualitatif berinteraksi dengan 
subjek penelitiannya secara alamiah, tidak menonjol dan tidak memaksa.(Moleong, 1996)

Dalam penelitian ini peneliti bertindak sebagai pengamat penuh. Kehadiran peneliti diketahui oleh objek. Ditetapkan indikator untuk diamati guna mendapatkan data awal dalam penelitian ini. Indikator dari variabel $\mathrm{X}$ maupun $\mathrm{Y}$.

Indikator Variabel X Tentang Budaya Antre

\begin{tabular}{|c|l|}
\hline Variabel X & \multicolumn{1}{|c|}{ Indikator } \\
\hline Budaya Antre & $\begin{array}{l}\text { 1. Anak memberi kesempatan } \\
\text { kepada orang lain. }\end{array}$ \\
\cline { 2 - 3 } & $\begin{array}{l}\text { 2. Anak dapat menunggu } \\
\text { giliran }\end{array}$ \\
\hline
\end{tabular}

\begin{tabular}{|c|c|}
\multicolumn{1}{l}{$\begin{array}{l}\text { Indikator } \\
\text { Kesabaran }\end{array}$} & Variabel $\quad$ tentang \\
\hline Variabel Y & \multicolumn{1}{c|}{ Indikator } \\
\hline Kesabaran & 1. Anak tidak lekas putus asa \\
\cline { 2 - 3 } & 2. Anak tidak lekas marah \\
\cline { 2 - 3 } & 3. Anak dapat tenang \\
\cline { 2 - 3 } & 4. Anak tidak tergesa-gesa \\
\hline
\end{tabular}

Dalam penelitian kualitatif sumber data primer diperoleh dengan observasi dan juga wawancara. Observasi dilakukan terhadap subjek penelitian yaitu anak TK A. Wawancara dilakukan terhadap responden yaitu orang tua murid dan guru. Juga digunakan dokumentasi untuk sumber data sekunder.

Wawancara. Digunakan kombinasi model wawancara dalam penelitian ini. Wawancara terstruktur digunakan untuk menanyakan hal-hal yang sudah diperkirakan sesuai indikator. Sementara wawancara tak terstruktur untuk memeroleh data yang mendalam sesuai situasi dan kondisi yang terjadi selama wawancara terstruktur berlangsung.

\section{Pertanyaan Untuk Orang Tua} Berdasarkan Variabel X Dan Y

\begin{tabular}{|c|l|}
\hline No. & \multicolumn{1}{|c|}{ Pertanyaan } \\
\hline 1. & $\begin{array}{l}\text { Apakah anak bapak/ibu lekas putus asa } \\
\text { ketika mengerjakan tugas yang diberikan. } \\
\text { Ya? Tidak? Mengapa? }\end{array}$ \\
\hline 2. & $\begin{array}{l}\text { Apakah anak bapak/ibu lekas marah ketika } \\
\text { lama menunggu giliran bermain dari kakak } \\
\text { atau adik. Ya? Tidak? Mengapa? }\end{array}$ \\
\hline 3. & $\begin{array}{l}\text { Apakah anak bapak/ibu dapat tenang } \\
\text { menunggu giliran bermain? Atau ketika } \\
\text { mainannya rusak. Ya? Tidak? Mengapa? }\end{array}$ \\
\hline 4. & $\begin{array}{l}\text { Apakah anak bapak/ibu memberi } \\
\text { kesempatan/mengalah kepada orang lain saat } \\
\text { bermain. Ya? Tidak? Mengapa? }\end{array}$ \\
\hline 5. & $\begin{array}{l}\text { Apakah anak bapak/ibu dapat menunggu } \\
\text { giliran saat bermain. Ya? Tidak? Mengapa? }\end{array}$ \\
\hline 6. & $\begin{array}{l}\text { Apakah anak bapak/ibu tergesa-gesa dalam } \\
\text { mengerjakan tugas atau ketika meminta } \\
\text { sesuatu. Ya? Tidak? Mengapa? }\end{array}$ \\
\hline
\end{tabular}

\section{Pertanyaan Untuk Guru Berdasarkan} Variabel X Dan Y

\begin{tabular}{|c|l|}
\hline No. & \multicolumn{1}{|c|}{ Pertanyaan } \\
\hline 1. & $\begin{array}{l}\text { Apakah X lekas putus asa ketika } \\
\text { mengerjakan tugas yang diberikan. Ya? } \\
\text { Tidak? Mengapa? }\end{array}$ \\
\hline 2. & $\begin{array}{l}\text { Apakah X lekas marah ketika lama } \\
\text { menunggu giliran bermain dari teman. Ya? } \\
\text { Tidak? Mengapa? }\end{array}$ \\
\hline 3. & $\begin{array}{l}\text { Apakah X dapat tenang menunggu giliran } \\
\text { bermain? Atau ketika mainannya rusak. Ya? } \\
\text { Tidak? Mengapa? }\end{array}$ \\
\hline 4. & $\begin{array}{l}\text { Apakah X memberi kesempatan/mengalah } \\
\text { kepada teman saat bermain. Ya? Tidak? } \\
\text { Mengapa? }\end{array}$ \\
\hline 5. & $\begin{array}{l}\text { Apakah X dapat menunggu giliran saat } \\
\text { bermain. Ya? Tidak? Mengapa? }\end{array}$ \\
\hline 6. & $\begin{array}{l}\text { Apakah X tergesa-gesa dalam mengerjakan } \\
\text { tugas atau ketika meminta sesuatu. Ya? } \\
\text { Tidak? Mengapa? }\end{array}$ \\
\hline
\end{tabular}

Dokumentasi. Data atau informasi yang diperoleh melalui dokumentasi untuk melengkapi informasi yang diperoleh dari wawancara dan observasi. Hal-hal yang didokumentasikan dalam foto-foto dan 
video yang bermakna adalah sebagai berikut:

\begin{tabular}{|c|l|}
\hline No. & \multicolumn{1}{|c|}{ Aspek yang didokumentasikan } \\
\hline 1. & $\begin{array}{l}\text { Penyambutan anak saat turun dari bus } \\
\text { sekolah }\end{array}$ \\
\hline 2. & Anak masuk kelas setelah berbaris \\
\hline 3. & Mencuci tangan di luar kelas \\
\hline 4. & $\begin{array}{l}\text { Aktivitas dalam kelas saat mengerjakan } \\
\text { tugas }\end{array}$ \\
\hline 5. & Bersalaman dengan guru \\
\hline 6. & Naik bus saat pulang sekolah \\
\hline
\end{tabular}

Analisa data. Data hasil wawancara, observasi, dan dokumen dianalisa secara deskriptif kualitatif, yaitu analisa data yang memberikan predikat kepada variabel yang diteliti sesuai kondisi sebenarnya.(Arikunto, 1990)

Analisa menggunakan kalimat yang menerangkan dan menjelaskan tentang pembiasaan antre pada anak yang berakibat pada perkembangan kesabaran. Perkembangan kesabaran dilihat dari kategori yang ditetapkan. Semakin banyak anak masuk kategori sangat tinggi dalam hal kesabaran menunjukkan bahwa pembiasaan budaya antre dapat menjadi sarana mengembangkan kesabaran anak.

\section{Hasil dan Pembahasan}

Pembiasaan budaya antre di TK Kristen Bina Kasih Terpadu dapat digambarkan sebagai berikut:

Saat anak mulai tiba di sekolah. Mulai pukul 08.00 WIB anak-anak datang kesekolah turun dari bus sekolah. Dua orang guru mendampingi, mengarahkan dan melihat anak-anak yang turun dari bus, memastikan anak turun satu persatu dengan aman sambil melakukan observasi terhadap anak-anak yang diteliti. Kemudian penyambutan anak, baris di halaman dan senam bersama.

Kegiatan mulai dan saat berada di kelas. Pukul 08.30 WIB masuk kedalam kelas.Saat memasuki ruangan kelas anak diarahkan mengantre oleh guru masingmasing sentra. Tujuannya supaya tidak berebut mendahului serta mendorong teman didepannya.Memberi penjelasan bahwa semua anak dapat giliran masuk walaupun membutuhkan waktu yang lebih lama.Meletakkan sepatunya dengan tertib di rak yang sudah disediakan. Anak duduk sesuai kelompok masing-masing lalu berdoa bersama, melakukan sircle time dan cerita karakter.

Lalu pukul 09.00 WIB penjelasan tentang tema dan melakukan sentra. Pukul 10.30 WIB mencuci tangan dengan berbaris memanjang,dipantau dan diarahkan dua orang guru.Anak-anak mengambil makanannya di diluar kelas dan membawanya masuk kemudian makan bersama.

Kegiatan selesai belajar dan kembali ke rumah. Pukul 11.00 WIB anak-anak pulang ke rumah dengan naik bus sekolah. Anak diarahkan kembali untuk mengantre.Guru mengatur anak yang 
rumahnya dekat sekolah mengantre paling akhir.Anak yang rumahnya paling jauh dari sekolah ditempatkan di belakang supaya memudahkan temannya yang dekat turun dari bus ketika sampai di depan rumah.

Pembiasaan budaya antre dilakukan setiap hari, dari Senin sampai Jumat. Mulai pukul 08.00 WIB sampai pukul 11.00 WIB. Hal tersebut dilakukan dengan maksud supaya anak semakin terlatih dalam kebiasaan mengantre. Kegiatan pembiasaan budaya antre anak di TK Kristen Benih Kasih Terpadu setiap hari mengalami perkembangan.

Berdasarkan wawancara dengan orang tua dipaparkan hasil dari tingkat kesabaran subjek penelitian. Dari indikator 1 tentang anak tidak lekas putus asa mengerjakan tugas, digambarkan sebagai berikut:

D kurang sabar, selalu tergesa-gesa dalam mengerjakan tugas yang diberikan. Jika melakukan sesuatu tidak bisa diatur dan diarahkan, hanya mendengarkan teguran sesaat. D anak super aktif. Jh sabar dalam mengerjakan tugas, tidak tergesa-gesa. Jo kurang sabar dalam mengerjakan tugas. Hanya mau mendengarkan teguran orang-orang tertentu. $\mathbf{N}$ sudah baik dalam mengerjakan tugas, tidak tergesa-gesa. Hanya saja sering melamun dan tidak mengerti apa yang sedang dikerjakan. Ra kurang sabar dalam mengerjakan tugas, tergesa-gesa mengerjakannya. Ra anak bungsu sehingga semua ingin dituruti. Kelebihan Ra adalah mau mendengar teguran dan menurutinya. Ri kesabarannya bagus, tidak tergesa dalam mengerjakan tugas. Ri perlu dituntun, diingatkan dan diarahkan. S masih kurang sabar dalam mengerjakan tugas. Yo juga perlahan-lahan dalam menyelesaikan tugasnya. Yo kurang sabar dalam mengerjakan tugas. Yo sulit menerima teguran, harus dengan dimarahi dulu oleh orang-orang tertentu yang bersuara keras. Lima dari sembilan subjek dalam indikator 1 belum menunjukkan kesabarannya. Masih pada tahap tidak atau kurang sabar dalam mengerjakan tugas sampai selesai.

Indikator 2 tentang anak tidak lekas marah ketika menunggu giliran bermain, enam anak dapat sabar menunggu giliran. Keenam anak tersebut adalah: D, Jh, N, $\mathbf{R a}, \mathbf{R i}$, serta $\mathbf{Y u}$. Tiga anak yaitu: Jo, $\mathbf{S}$ dan Yo kurang sabar menunggu gilirannya bermain.

Indikator 3 tentang anak dapat tenang menunggu giliran bermain atau ketika mainannya rusak, dapat dijabarkan sebagai berikut: lima anak yakni Jh, Jo, $\mathbf{R i}$, S, dan Yo, dapat tenang menunggu giliran bermain dan bersabar ketika mainannya dirusakkan teman. Empat anak yaitu: D, N, Ra, dan Yu tidak/kurang sabar ketika hal tersebut terjadi. 
Indikator 4 tentang anak memberi kesempatan teman/mengalah saat bermain. Hasilnya adalah: enam anak mau mengalah atau memberi kesempatan bermain pada teman. Jh mau mengalah kepada adiknya, tidak mau bertengkar dengan teman jika ada teman yang memarahinya. $\mathbf{N}$ mau mengalah dan berbagi mainan dengan teman. Yo mau bekerja sama dan mengalah dengan temannya. Demikian juga, S, Jo dan Yu. Tiga anak yaitu D, Ra, dan Ri masih belum bisa mengalah kepada teman.

Indikator 5 tentang anak dapat menunggu giliran, hasilnya adalah sebagai berikut: hanya ada satu anak yaitu Ri yang belum dapat menunggu giliran bermain. Sementara delapan lainnya dapat menunggu giliran bermain.

Indikator 6 tentang anak tidak tergesa-gesa dalam mengerjakan tugas dan antre turun naik bus, menunjukkan hasil sebagai berikut, lima anak yaitu: Jh, Ra, Ri, S, dan Yusabar dalam mengerjakan tugas dan bersabar saat antre naik turun bis sekolah. Empat yang lain yaitu: D, Jo, Yo, dan $\mathbf{N}$ tidak/kurang sabar.

Kesimpulan dari wawancara dengan semua orang tua subjek adalah rata-rata tingkat kesabaran anak dapat dikatakan antara kurang sampai cukup.

Hasil dari wawancara guru pertama (Mesranitati Ndruru) menunjukkan hasil tingkat kesabaran anak-anak di sekolah hampir sama dengan wawancara dengan orang tua sewaktu anak di rumah bersama kakak, adik, dan teman. Semua berada dalam tingkat kurang sampai cukup sabar.

Dari wawancara dengan guru kedua (Esti Halena Lenamah) untuk indikator 3 tentang anak dapat tenang menunggu giliran bermain atau ketika mainannya rusak, tingkat kesabaran anak dalam kondisi rendah atau tidak sabar. Ada enam anak yang tidak sabar yaitu: D, Jo, N, Ri, Yo, dan Yu. Juga dalam indikator 6 yaitu tentang anak tidak tergesa-gesa dalam mengerjakan tugas dan antre turun naik bus, ada enam anak yang tidak sabar. Keenam anak tersebut adalah: D, Ra, Ri, Yo, S, dan Yu.

Jadi dari hasil wawancara orang tua dan guru hasilnya sama, tingkat kesabaran anak rata-rata kurang sampai cukup.

Hasil observasi sebagai berikut: untuk indikator 1 tentang anak tidak lekas putus asa mengerjakan tugas, D masuk kategori 1(kurang baik). D tergesa-gesa jika mengerjakan dan meraih sesuatu. Tujuh anak mencapai kategori baik. Yo masuk kategori 3 (sangat baik), dalam keseharian taat dan mau mendengarkan nasehat guru, tidak tergesa-gesa dalam mengerjakan tugas. Kesimpulan untuk indikator 1, rata-rata anak dapat dikatakan sudah baik tingkat perkembangan kesabarannya. 
Indikator 2 tentang anak tidak lekas marah ketika menunggu giliran bermain, empat anak masuk kategori 3 (sangat baik), tiga anak masuk kategori 2 (baik) dan dua anak masuk kategori 1 (kurang baik). Jo saat bermain tidak sabar, kadang membuat teman terluka karena ketidaksabarannya. Hanya mau mendengarkan teguran orang-orang tertentu. Ri sering melakukan tindakan usil dan mengganggu teman yang antre bermain. Ri melakukan hal tersebut karena ingin diperhatikan oleh oleh. Hal baik adalah ketika diberi nasehat dan teguran $\mathbf{R i}$ mau mendengarkan. Secara keseluruhan indikator 2 anak ada pada tingkat baik sampai sangat baik.

Indikator 3 tentang anak dapat tenang menunggu giliran bermain atau ketika mainannya rusak, D dan Jo masuk kategori 1 (kurang baik). D kurang mampu menguasai emosi saat antre, demikian juga Jo. Sementara tujuh anak yang lain masuk kategori baik dan sangat baik perkembangan tingkat kesabarannya.

Indikator 4 tentang anak memberi kesempatan teman/mengalah saat bermain. Semua anak ada pada tingkat perkembangan kesabaran baik dan sangat baik.

Indikator 5 tentang anak dapat menunggu giliran, Jo mendapat kategori 1 (kurang baik). Anak ini kadang mendahului teman di depannya saat antre.
Anak-anak yang lain berkembang baik dan sangat baik.

Indikator 6 tentang anak tidak tergesa-gesa dalam mengerjakan tugas dan antre turun naik bus, D dan Jo masuk kategori 1 (kurang baik). Jo kadang mendahului teman ketika akan masuk bus sekolah.

Dari semua instrumen pengumpulan data, hasil yang diperoleh adalah anakanak TK Kristen Benih Kasih Terpadu usia 4-5 tahun perkembangan kesabarannya ada pada tingkat baik sampai sangat baik. Hanya dua anak yaitu D dan Jo yang masih kurang tingkat perkembangan kesabarannya.

Analisa temuan data. Dari hasil wawancara dan observasi menunjukkan hasil: siswa TK Kristen Benih Kasih Terpadu dalam perkembangan tingkat kesabaran melalui pembiasaan budaya antre menunjukkan hasil yang baik.

Usia 4 atau 5 tahun, anak mulai bermain dalam kelompoknya. Saling berbicara saat bermain, dan memilih siapa yang diajak bermain bersama. Hal paling umum dilakukan kelompok ini adalah saling mengamati, bercakap-cakap, dan memberi saran lisan.

Dalam kondisi inilah anak-anak belajar bersabar untuk menunggu giliran dalam bermain dalam kelompoknya. Serta belajar mengembangkan sosio emosionalnya. 
Perkembangan perilaku manusia dipengaruhi oleh perubahan budaya. Perkembangan individu dibentuk agar dapat menyesuaikan diri dengan standar budaya dan segala hal yang ideal. Perubahan yang terjadi dalam standar tersebut akan memengaruhi pola perkembangan perilakunya. Hal ini seperti dikatakan oleh Elisabeth Hurlock bahwa perkembangan kesabaran individu (anak) dipengaruhi oleh perubahan budaya dan hal tersebut akan memengaruhi individu untuk menyesuaikan diri.

Murid TK Bina Kasih, diubah budayanya agar meningkat kesabarannya. Guru-guru di sekolah membiasakan budaya antre yang mungkin oleh orang tua di rumah tidak begitu ketat. Guru-guru menggunakan proses belajar mengajar untuk membiasakan budaya antre sejak anak-anak turun dari bus sekolah, saat masuk kelas, mengerjakan tugas-tugas, makan bersama, cuci tangan sebelum dan sesudah makan, bermain, hingga kembali naik bus pulang ke rumah.

Hasilnya adalah anak terbiasa antre dan terjadi peningkatan kesabaran pada tingkat kategori baik dan sangat baik.

\section{Kesimpulan}

Dari wawancara serta observasi menunjukkan anak-anak usia 4-5 tahun siswa TK Kristen Benih Kasih Terpadu dalam perkembangan tingkat kesabaran melalui pembiasaan budaya antre menunjukkan hasil yang baik.

Siswa TK Bina Kasih, diubah budayanya agar meningkat kesabarannya. Guru-guru di sekolah membiasakan budaya antre yang mungkin oleh orang tua di rumah tidak begitu ketat. Guru-guru menggunakan proses belajar mengajar untuk membiasakan budaya antre sejak anak-anak turun dari bus sekolah, saat masuk kelas, mengerjakan tugas-tugas, makan bersama, cuci tangan sebelum dan sesudah makan, bermain, hingga kembali naik bus pulang ke rumah.

Hasilnya adalah anak terbiasa antre dan terjadi peningkatan kesabaran pada kategori baik dan sangat baik. Jadi kesimpulannya adalah pembiasaan antre dapat menaikkan tingkat kesabaran siswa kelompok A TK Kristen Bina Kasih Terpadu.

Perlu bagi TK Kristen Bina Kasih untukTerus meningkatkan pembiasaan budaya antre dan juga pendekatan khusus untuk dua anak yang masih berada di kategori 1 (kurang baik) tingkat kesabarannya.

Melakukan pendekatan kepada orang tua murid untuk juga membiasakan budaya antre di rumah, supaya upaya guru di sekolah terus berkesinambungan di rumah. Sebab mengembangkan dan membangun karakter anak adalah tugas utama orang tua yang bersinergi dengan guru. 


\section{Daftar Pustaka}

Afrizal. (2014). Metode Penelitian Kualitatif.

Akilasari, Y., Risyak, B., \& Sabdaningtyas, L. (2015). Faktor Keluarga, Sekolah dan Teman Sebaya Pendukung Kemampuan Sosial Anak Usia Dini. Jurnal Pendidikan Anak, 1(5).

Arikunto, S. (1990). Manajemen Pendidikan.

Budiardjo, T. (2011). Pelayanan Anak yang Holistik. Yogyakarta: Andi.

Cahyaningrum, E. S., Sudaryanti, S., \& Purwanto, N. A. (2017). Pengembangan nilai-nilai karakter anak usia dini melalui pembiasaan dan keteladanan. Jurnal Pendidikan Anak, 6(2), 203-213.

Hidayah, Z. (2008). Budaya Antre Masyarakat Kota Yogyakarta. Yogyakarta:Departemen

Pendidikan Dan Kebudayaan.

Hurlock, E. B. (1978). Perkembangan Anak (terjemahan). Erlangga: Jakarta.

Ismiyati, I., Firdaus, M., \& Arubusman, D. A. (2016). Manajemen Pemeliharaan Bus Transjakarta Dalam Mencapai Standar Pelayanan Minimum. Jurnal Manajemen Transportasi \& Logistik, 3(2), 185-203.
Keriapy, F. (2020). Pendidikan Kristiani Transformatif Berbasis Multikultural dalam Konteks Indonesia. REGULA FIDEI: Jurnal Pendidikan Agama Kristen, 5(2), 82-93.

Koentjaraningrat, R. (1981). Kebudayaan, Mentalitas dan Pembangunan [Culture, Mentality and Development]. Jakarta: Gramedia. Lexy, J. M. (2002). Metodologi penelitian kualitatif. Bandung: Remaja Rosdakarya.

Listyandari, R. (2013). Jangan Tunda Mencetak Anak Hebat! Gramedia Pustaka Utama.

Moleong, L. (1996). Metodologi Penelitian Kualitatif,

Monks, F. J., Knoers, A., \& Haditono, S. R. (2002). Psikologi perkembangan. Pengantar Dalam Berbagai Perkembangannya. Yogyakarta: Gadjah Mada Univesity Perss.

Romini, R., \& Harefa, I. D. (2020). MANFAAT PENGGUNAAN ALKITAB BERGAMBAR TERHADAP PERKEMBANGAN KEROHANIAN ANAK FUTURE CENTER USIA 7-9 TAHUN DI BULUH AWAR. EDULEAD: Journal of Christian Education and Leadership, 1(1), 1-14. 
Sit, M. (2017). Psikologi Perkembangan Anak Usia Dini Edisi Pertama. Kencana.

Sujarwati, W. (2014). Metodologi Penelitian.

Zainal, A. (2012). Ilmu Sosial dan Budaya Dasar. ANDI. 